\title{
Is EU Supranational Governance a Challenge to Liberal Constitutionalism?
}

\author{
Gráinne de Búrca†
}

\begin{abstract}
Does supranational governance present a challenge to liberal constitutionalism? More particularly, has the European Union's supranational form of governance fueled the rise of illiberal authoritarianism and undermined liberal constitutionalism? This Essay first addresses two related empirical questions associated with this larger query: first, whether the Brexit vote reflected a rise in authoritarianism and a turn against liberal constitutionalism; and second, whether the Euroscepticism to which the process of European integration has given rise has also contributed to the growth of the illiberal far right across the European Union and to the weakening of support for liberal constitutionalism. The third part addresses a broader and more conceptual question about the relationship between supranational governance and liberal constitutionalism-namely, whether there is something either inherent or contingent in the structure and process of European integration and in the project of European supranational governance that creates a challenge to liberal constitutionalism and, if so, what kind of challenge.
\end{abstract}

\section{INTRODUCTION}

The European Union was founded in the 1950s as an experiment in postwar regional integration, in part to help rebuild national economies damaged by World War II through economic integration, and in part to ward off, by means of closer legal and political integration of states, the threat of totalitarianism and Soviet expansion. ${ }^{1}$ For a number of decades the experiment in European integration made considerable progress toward these goals, deepening economic, legal, and political integration at the same time as it expanded to include many of the Central and Eastern Europe Countries (CEEC). ${ }^{2}$ The project of eastward expansion also meant that the European Union came to be viewed

$\dagger$ Florence Ellinwood Allen Professor of Law, NYU Law School. I am grateful to Thomas Streinz and the participants at The University of Chicago Law Review Symposium on The Limits of Constitutionalism in May 2017 and the Philosophy Colloquium at NYU in September 2017 for their comments and suggestions.

1 For an analysis of the origins of the European Union, see generally Alan S. Milward, The European Rescue of the Nation-State (Routledge 1992).

2 See generally Marise Cremona, ed, The Enlargement of the European Union (Oxford 2003). 
not just as a project of economic and political integration of Western Europe, but also one of democratization and democracy promotion.

The imposition of a form of political conditionality on the process of accession to the European Union had begun in the 1970s and 1980s when Spain, Portugal, and Greece were admitted following periods of domestic dictatorship. ${ }^{3}$ This process was expanded and formalized in the 1990s with the adoption of the Copenhagen criteria by the EU heads of state in the European Council prior to the opening of accession negotiations with the CEEC. ${ }^{4}$ These criteria are a set of requirements that commit all states seeking to join the European Union to respect the principles on which it is founded-namely, "the principles of liberty, democracy and respect for human rights and fundamental freedoms and of the rule of law" 5 _ and that are now enshrined in Article 49 and Article 6(1) of the Treaty on European Union (TEU). ${ }^{6}$ Further, since 1997, the TEU has included a procedure, known as the Article 7 sanction mechanism, that provides for the possible suspension of voting rights of an EU member state that seriously and persistently breaches these principles. ${ }^{7}$

In other words, the European Union, as it stands today, seems to be designed at least in part to protect and promote democracy and liberal constitutionalism, rather than to undermine or weaken it. Why then do we need to pose the question whether supranational governance presents a challenge to liberal constitutionalism? A first answer is that the European Unionparticularly since the time of the Maastricht Treaty in 1992, which heralded the move from an "economic community" to a

\footnotetext{
3 See generally Frank Schimmelfennig and Hanno Scholtz, Legacies and Leverage: EU Political Conditionality and Democracy Promotion in Historical Perspective, 62 EurAsia Stud 443 (2010); Viljar Veebel, European Union's Positive Conditionality Model in Pre-accession Process, 13 Trames 207, 213-20 (2009).

4 See European Council, Conclusions of the Presidency *13 (June 21-22, 1993), archived at http://perma.cc/42XZ-8YLS ("Membership requires that the candidate country has achieved stability of institutions guaranteeing democracy, the rule of law, human rights and respect for and protection of minorities, the existence of a functioning market economy as well as the capacity to cope with competitive pressure and market forces within the Union.").

5 Consolidated Version of the Treaty on European Union, 55 J EU C326 13, 15 (2012) (“TEU”).

6 See TEU Arts 6(1), 49, 55 J EU C326 at 19, 43.

7 TEU Art 7, $55 \mathrm{~J}$ EU C326 at 19-20.
} 
more ambitious political union with a single currency ${ }^{8}$ - has experienced a series of ongoing challenges to its legitimacy, including recurrent allegations of a "democratic deficit." Secondly, the European Union over the past decade has been roiled by a series of even sharper crises, including the Euro crisis and the refugee crisis, leading to a set of challenges that go well beyond the democratic-deficit critique. Among them is the rise within many member states of Eurosceptical political movements, in some cases accompanied by a growth in support for illiberal authoritarian government, as seen most strikingly in Poland and Hungary.

Further, the Brexit vote of a majority of the UK population in 2016 to leave the European Union has presented another major problem for the European Union. The apparent similarities between the wider move against liberal constitutionalism described in the Symposium Introduction ${ }^{9}$ and some of the causes and manifestations of the Brexit vote in the United Kingdom raise the question whether the vote itself can be understood as part of this wider move away from liberal constitutionalism and toward increasingly authoritarian rule.

In what follows, three questions are addressed. The first is whether the Brexit vote can indeed be understood as part of the move away from liberal constitutionalism, or whether this claim overstates the similarity between the UK vote to leave the European Union and the erosion of constitutional democracy in other states. The second is whether the EU project of regional integration may be partly responsible for the rise of authoritarianism and the decline in support for liberal constitutionalism within several of the EU member states. The third and final question is whether the EU form of supranational governance itself presents a challenge to liberal constitutionalism, as defined in the Symposium Introduction. ${ }^{10}$

\footnotetext{
8 Maastricht Treaty Title II, 35 J EU C191 1, 5 (1992).

9 See Tom Ginsburg, Aziz Z. Huq, and Mila Versteeg, The Coming Demise of Liberal Constitutionalism?, 85 U Chi L Rev 239, 239-42 (2018).

10 Professors Tom Ginsburg, Aziz Z. Huq, and Mila Versteeg have described liberal constitutionalism as entailing: a written constitution including an enumeration of individual rights; the existence of rights-based judicial review; a heightened threshold for constitutional amendment; a commitment to persisting democratic elections; and a commitment to the rule of law, understood as ensuring that administrative and adjudicative functions that operate autonomously from, and potentially limit, powerful factions or leaders. Id at 239 .
} 


\section{DiD The BREXit Vote REFLECT A DECLINE IN SUPPORT FOR LIBERAL CONSTITUTIONALISM?}

On one interpretation, the vote of a majority of the population of the United Kingdom to leave the European Union had little to do with a rejection of liberal constitutionalism. The strongly Eurosceptic sentiment that underpinned much of the "leave" vote-a sentiment that has been prominent in the United Kingdom since it first joined the European Economic Community (EEC) in 1973, fluctuating at times but rising in recent years ${ }^{11}$ was skeptical of the European Union and the benefits of European integration, but not necessarily skeptical of Britain's traditional democratic system. The strongest two factors that appear to have led those voting against EU membership to do so were specific concerns over immigration and a more general desire to regain "control," including control of the economy, of borders, and of lawmaking. ${ }^{12}$ Indeed, a popular referendum is certainly at least one dimension of democracy in practice, albeit one which can be in tension with elements of representative democracy or with minority rights and other constitutional guarantees. And the design of the Brexit referendum has been criticized on account of its failure to build in safeguards like a supermajority requirement or a "double-lock threshold" to reflect the role of the devolved regions in the UK. ${ }^{13}$ Nevertheless, the concerns over immigration and desire for greater national control that were reflected in the British vote to leave the European Union do not necessarily imply a rejection of liberal constitutionalism or a vote for illiberal authoritarianism.

Indeed, the Brexit vote could reasonably be understood as the almost inevitable consequence of the immense gamble of putting to a popular vote (on perhaps any number of occasions over the past thirty years) the question of UK membership in the European Union. Despite the shock with which the result of the vote was

\footnotetext{
11 See Roger Mortimore, Polling History: 40 Years of British Views on 'In or Out' of Europe (The Conversation, June 21, 2016), archived at http://perma.cc/U245-DH3Q.

12 See Brexit Britain: British Election Study Insights from the Post-EU Referendum Wave of the BES Internet Panel (British Election Study, June 10, 2016), archived at http://perma.cc/7SZ4-NZXG; Matthew J. Goodwin and Oliver Heath, The 2016 Referendum, Brexit and the Left Behind: An Aggregate-Level Analysis of the Result, 87 Polit Q 323, 324-25 (2016).

13 See Allan F. Tatham, "The Art of Falling Apart?": Constitutional Conundrums Surrounding a Potential Brexit *6-7 (CSF-SSSUP Working Paper Series, Feb 2015), archived at http://perma.cc/XF3Z-BC9Q; Kenneth Rogoff, Britain's Democratic Failure (Project Syndicate, June 24, 2016), archived at http://perma.cc/TM5D-HGG8.
} 
greeted, it was in many respects a predictable outcome given how continuously contested and difficult the United Kingdom's relationship with the European Union has been ever since it joined. The United Kingdom initially sought EU membership for largely pragmatic economic reasons rather than any commitment to being part of a European political unity. ${ }^{14}$ Throughout its more than forty-year membership, Britain never subscribed to or supported the vision of European integration accepted by many, if not most, other member states.

On the contrary, the United Kingdom adopted a pragmatic and often ad hoc approach to its EU membership, with numerous opt-outs and special treatment sought over the years. While other member states expressed reservations at various times about aspects of EU policy and sought occasional opt-outs for particular interests and issues, ${ }^{15}$ the United Kingdom nonetheless remained quite exceptional if not exceptionalist in its attitude toward the European Union, and the attitude of its government in general largely reflected public opinion. Britain sought and received special treatment in relation to the so-called EU budget rebate, ${ }^{16}$ and it adopted a pragmatic, case-by-case approach to the introduction of new areas of EU policy. Thus, the United Kingdom secured optouts on a range of issues on which it was unwilling to countenance closer integration. Notably, these included reprieves from economic and monetary union (EMU) and Justice and Home Affairs at the time of the Maastricht Treaty, with other shorter-lived or less successful attempts seen in the Social Protocol attached to the Maastricht Treaty ${ }^{17}$ and the more recent Protocol on the Charter of Fundamental Rights attached to the Lisbon Treaty. ${ }^{18}$

14 See Nauro Campos and Fabrizio Coricelli, Why Did Britain Join the EU? A New Insight from Economic History (Vox EU, Feb 3, 2015), archived at http://perma.cc/SS7K-PR3N.

15 Denmark and Ireland, for example, have chosen to opt out from some of the EU provisions on Justice and Home Affairs, and Denmark and Sweden have chosen to remain outside the euro. Various other minor opt-outs have been secured from time to time by other EU members, but no member state has requested and obtained the number and range of opt-outs that the United Kingdom consistently has. See Mark Briggs, Europe 'à la Carte: The Whats and Whys behind UK Opt-Outs (Euractiv, May 12, 2015), archived at http://perma.cc/8B9J-ZG3R.

16 See generally Alessandro D'Alfonso, The UK 'Rebate' on the EU Budget: An Explanation of the Abatement and Other Correction Mechanisms (European Parliamentary Research Service, Feb 2016), archived at http://perma.cc/73S7-KEQG.

17 See, for example, Brian Towers, Two Speed Ahead: Social Europe and the UK after Maastricht, 23 Indust Rel J 83, 85 (1992); Gerda Falkner, The Maastricht Protocol on Social Policy: Theory and Practice, 6 J Eur Soc Pol 1, 9-10 (1996).

18 See generally Catherine Barnard, The 'Opt-Out' for the UK and Poland from the Charter of Fundamental Rights: Triumph of Rhetoric over Reality?, in Stefan Griller and 
Euroscepticism in the United Kingdom, as evidenced also by opinion poll research, ${ }^{19}$ has long predated the current wave of populism sweeping the democratic world, ${ }^{20}$ and it has expressed itself for the most part not as a rejection of liberal democratic values but as something that could even be presented as the opposite: a refusal to be "ruled from abroad," as voters understood it, and a rejection of the primacy of "continental" and unresponsive European supranational law over domestic constitutional law and domestic democratic institutions. On this reading, despite the similarity in the salience of the issues of immigration, economic insecurity, and nationalism, the Brexit vote to leave the European Union might perhaps not be so easily categorized with the various political movements in other European states and the United States that seem to challenge core aspects of constitutional democracy and to advance illiberal populism. Despite the antisystem flavor of the referendum, the apparent wish of many of those who voted for Brexit could be said to have been to reject the European Union's role in the United Kingdom, rather than to replace or undermine aspects of the British democratic and constitutional system.

Yet at the same time, this first interpretation of the Brexit referendum overlooks various features of the vote and particularly the nature of the issues that fanned the flames of the longstanding, latent Euroscepticism that eventually led to a majority vote in favor of withdrawal from the European Union. Certain aspects of the vote and its underlying causes resonate clearly with what was referred to in the Symposium Introduction as the "right-leaning populist explosion" across Europe and Asia.21 While the Brexit debate in the United Kingdom did not generally entail calls or proposals to repudiate liberal norms of tolerance, restrict press freedom, or undermine the rule of law, certain dimensions of the vote to leave-and perhaps particularly the dimensions that tipped the balance this time toward a "no" votesuggest that important elements of the illiberal populism evident

Jacques Ziller, eds, The Lisbon Treaty: EU Constitutionalism without a Constitutional Treaty? 257 (SpringerWienNewYork 2008).

19 See Mortimore, Polling History (cited in note 11).

20 See generally Anthony Forster, Euroscepticism in Contemporary British Politics: Opposition to Europe in the British Conservative and Labour Parties since 1945 (Routledge 2002).

21 See Ginsburg, Huq, and Versteeg, 85 U Chi L Rev at 240 (cited in note 9) (quotation marks omitted). 
elsewhere in Europe and beyond were present also in the UK debate and in the size of the vote to leave.

In the first place, various analyses of the British vote postreferendum indicate that the issue of immigration and the prevalence of anti-immigrant sentiment played a very significant role in the vote. ${ }^{22}$ While concern over immigration is not necessarily illiberal, widespread anti-immigrant sentiment during the Brexit campaign erupted regularly into xenophobic discourse and racism, as was widely reported in the British media at the time. ${ }^{23}$ Further, according to police records, the period following the referendum vote showed a sharp rise in hate crimes directed at migrants and refugees. ${ }^{24}$

In the second place, a clear correlation between anti-EU sentiment and attachment to authoritarian values was identified in a number of post-referendum studies of the Brexit vote. In particular, it seems that 66 percent of those who voted to leave the European Union identified themselves as having values that were coded as "authoritarian" on the authoritarian-libertarian scale. ${ }^{25}$ Attachment to these authoritarian values was revealed in responses to a range of questions, such as those concerning how children should be raised and attitudes toward the death penalty,

22 See Kirby Swales, Understanding the Leave Vote *13 (NatCen Social Research, 2016), archived at http://perma.cc/X5ES-2MFF; Harold D. Clarke, Matthew Goodwin, and Paul Whiteley, Why Britain Voted for Brexit: An Individual-Level Analysis of the 2016 Referendum Vote, 70 Parliamentary Aff 439, 453 (2017).

23 See, for example, Brett Arends, Brexit Campaign Devolves into Racism and Xenophobia (MarketWatch, June 15, 2016), online at http://www.marketwatch.com/ story/brexit-campaign-devolves-into-racism-and-xenophobia-2016-06-15 (visited Dec 13, 2017) (Perma archive unavailable).

24 See Jon Burnett, Racial Violence and the Brexit State *13 (Institute of Race Relations, 2016), archived at http://perma.cc/G45C-BKY3. For media reports, see Katie Forster, Hate Crimes Soared by $41 \%$ after Brexit Vote, Official Figures Reveal (The Independent, Oct 13, 2016), archived at http://perma.cc/8WGV-WSXT; Homa Khaleeli, 'A Frenzy of Hatred': How to Understand Brexit Racism (The Guardian, June 29, 2016), archived at http://perma.cc/S7LT-BPTJ.

25 See Swales, Understanding the Leave Vote at *16 (cited in note 22). See also Eric Kaufmann, It's NOT the Economy, Stupid: Brexit as a Story of Personal Values (London School of Economics, July 7, 2016), archived at http://perma.cc/64C6-7BF2. Political values in the United Kingdom have for some decades been measured by social scientists on a libertarian-authoritarian scale as well as a left-right scale, see, for example, UK Parties 2017 General Election (Political Compass, Aug 22, 2017), archived at http://perma.cc/7SR4-LYTJ, and it seems that the libertarian-authoritarian cleavage was much more significant in the Brexit vote than the left-right cleavage. 
but also in responses indicating a preference in certain circumstances for order over personal freedom. ${ }^{26}$

Thirdly, in the aftermath of the vote to leave the European Union, a more vocally illiberal element has been present in the public debate. There were extraordinary verbal attacks by the popular tabloid press on the judiciary. Headlines proclaimed the judges of the High Court to be "enemies of the people" following the $R$ (Miller) $v$ Secretary of State for Exiting the European Union ${ }^{27}$ case. ${ }^{28}$ Miller declared that a decision to trigger Article 50 of the TEU, which would begin the countdown to withdrawal, required a parliamentary vote. ${ }^{29}$ Further, there has been intense pressure to effectively entrench the result of the (nonbinding) referendum vote and to treat any debate or discussion of the merits of the vote as a betrayal of the people's voice. ${ }^{30}$

Fourthly, one of the sources of opposition to the European Union among an important category of pro-Brexit voters was the role of the European Court of Justice (ECJ) and its rulings on the EU Charter of Fundamental Rights. ${ }^{31}$ This objection to European adjudication of issues raising human-rights claims in the United Kingdom, and its prominence in the Brexit debate, extended also to the rulings of the European Court of Human Rights (ECtHR) in Strasbourg, which although not formally part of the EU system is closely linked to it. Thus Theresa May-in her capacity as

26 The issues on which they were asked whether they agreed or disagreed included the following: (1) Young people today don't have enough respect for traditional British values; (2) People who break the law should be given stiffer sentences; (3) For some crimes, the death penalty is the most appropriate sentence; (4) Schools should teach children to obey authority; (5) The law should always be obeyed, even if a particular law is wrong; (6) Censorship of films and magazines is necessary to uphold moral standards. See Swales, Understanding the Leave Vote at *28 (cited in note 22).

27 [2016] EWHC 2768 (Admin).

28 See James Slack, Enemies of the People: Fury over 'Out of Touch' Judges Who Have 'Declared War on Democracy' by Defying 17.4m Brexit Voters and Who Could Trigger Constitutional Crisis (Daily Mail, Nov 4, 2016), online at http://www.dailymail.co.uk/news/ article-3903436/Enemies-people-Fury-touch-judges-defied-17-4m-Brexit-voters-trigger -constitutional-crisis.html (visited Oct 16, 2017) (Perma archive unavailable).

29 Miller, [2016] EWHC 2768 at 9 92-93. The judgment of the Supreme Court on appeal was given on January 24, 2017. See $R$ (Miller) $v$ Secretary of State for Exiting the European Union, [2017] UKSC 5.

30 See Anatole Kaletsky, Tony Blair's Democratic Insurrection (Project Syndicate, Feb 24, 2017), archived at http://perma.cc/A6SA-CQDM.

31 An influential blog article published in February 2016 by Marina Wheeler, a senior lawyer and the spouse of Boris Johnson, the then-London mayor who led the Brexit campaign, argued that the power of the ECJ had been extended too far by the EU Charter of Fundamental Rights. See Marina Wheeler, Cavalier with Our Constitution: A Charter Too Far (UK Human Rights Blog, Feb 9, 2016), archived at http://perma.cc/K8QV-8UJD. 
then-Home Secretary in April 2016-called for UK withdrawal from the European Convention on Human Rights (ECHR), and despite mixed messages from the British government on this subject since that time, the question of withdrawal from the ECHR, repeal of the UK Human Rights Act, and rejection of the EU Charter of Fundamental Rights and the jurisdiction of the ECJ have been treated as closely related in the Brexit and postBrexit debate. ${ }^{32}$

Hence the Brexit vote, while on a first analysis may not appear to have much in common with the spread of illiberal authoritarianism in countries like Poland and Hungary, does share a number of relevant features, including (i) a strong antiimmigration and anti-immigrant dimension, (ii) an increasingly publicly expressed intolerance (fueled by the tabloid media) toward dissent or disagreement with the voice of the "people" as taken to be expressed by the June 2016 vote, (iii) the fact that a majority of those who were identified in a poll as adhering to authoritarian values voted for Brexit, and (iv) a rejection of humanrights adjudication by European courts. The British political system did not move toward becoming an illiberal authoritarian regime in the aftermath of the Brexit vote, but many of the elements that have come to prominence in other states and that have fueled the rise of illiberal regimes in those other countries were also present in the United Kingdom, with the vote revealing a very divided society sharply split between those on the authoritarian and those on the liberal side of the political spectrum. The risk recently articulated by several political science scholars that the discourse, policies, and preferences of the vocal far right (including their populist illiberalism) is likely to strongly influence the programs and actions of mainstream and centrist parties, is clearly present in the post-Brexit United Kingdom. ${ }^{33}$

32 See Anushka Asthana and Rowena Mason, UK Must Leave European Convention on Human Rights, Says Theresa May (The Guardian, Apr 25, 2016), archived at http://perma.cc/J3DD-9VJH; Ed Bates, Is the UK Going to Withdraw from the ECHR? What about the Human Rights Act? (ukstrasbourgspotlight, Mar 10, 2017), archived at http://perma.cc/CX8U-LBFR. For an analysis by the UK Parliamentary Joint Committee on Human Rights, see generally House of Common and House of Lords Joint Committee on Human Rights, The Human Rights Implications of Brexit (Dec 19, 2016), archived at http://perma.cc/U3V9-NEHV.

33 See Cas Mudde, On Extremism and Democracy in Europe 145-48 (Routledge 2016). Professor Cas Mudde warns that democracy in Europe is under threat from the liberal elite, who are choosing to adapt their programs and policies (on issues such as migration, refugees, and multiculturalism) to the agenda of the far right in order to win voters. 
These elements in the Brexit debate, however, do not necessarily establish that the European Union presents a challenge to liberal constitutionalism, even if they indicate that a significant part of the opposition to the European Union in the United Kingdom was illiberal in nature, involving a strong reaction against migration and migrants, and against rights adjudication by European judges, and toward the identification of the Brexit majority vote as the true voice of the people. The question whether the process of European integration has generated such reactions elsewhere in the European Union is explored in the next Part.

\section{Has EU Integration Played A PART IN THE Rise IN SUPPORT FOR ILLIBERAL AUTHORITARIAN PARTIES ACROSS MEMBER STATES AND A DECLINE IN SUPPORT FOR LIBERAL CONSTITUTIONALISM?}

It is certainly clear that the process of European integration has given rise to political and social movements opposed to the European Union and to the project of integration, a phenomenon that is commonly known as Euroscepticism. ${ }^{34}$ One empirical question arising from this fact is whether the growth of Euroscepticism in response to European integration has fueled the decline in support for liberal constitutionalism and the rise of illiberal authoritarianism.

This is a complex question, and one that cannot be answered with any degree of accuracy without careful empirical analysis of a range of countries over time. For present purposes, I will simply identify and describe a set of distinct phenomena that bear on the question, and consider some of the possible relationships between them. There are at least three movements or sets of developments across various states of the European Union that seem relevant to the question. The first is the steady growth of Euroscepticism over several decades, the second is the gradual rise of the far right across Europe, and the third is the more general turn in many European countries (including EU states) against what has been described as global neoliberal capitalism.

The first of these, the rise of Euroscepticism, has been the subject of intensive study and analysis since the mid-1990s, when it initially began to manifest in the aftermath of the Maastricht Treaty and the move from the EEC to the European Union. The

34 For an early collection of essays on Eurosceptical thought, see generally Martin Holmes, ed, The Eurosceptical Reader (St. Martin's 1996). 
opposition that began to grow was, in a sense, a challenge to the elite consensus in favor of European integration that had prevailed since the 1950s, together with the assumption of a popular "permissive consensus" accompanying this elite support. ${ }^{35}$ With the introduction of economic and monetary union, a common foreign and security policy, and an aspiration toward political union in the Maastricht treaty in 1993, political opposition toward the European Union began to develop in earnest. ${ }^{36}$ Since that time, Euroscepticism - and particularly what has been termed "hard" Euroscepticism entailing opposition to the very idea of European integration, rather than "soft" Euroscepticism entailing objection to some of the EU policies and direction-has continued to rise steadily. ${ }^{37}$ This Euroscepticism has not been the domain exclusively of the right or the far right, however. On the contrary, there has always been a strand of Euroscepticism on the left. ${ }^{38}$ Nevertheless, left-wing Euroscepticism has been a less prominent strand than that of the Eurosceptical right, and unlike rightwing Euroscepticism, which has generally opposed the project of European integration, left-wing Euroscepticism has broadly been in favor of reform of the European Union rather than outright opposition to its existence. ${ }^{39}$

However, with the two major crises that hit the European Union from 2007 onwards-first, the European debt and banking crisis, followed by the refugee and migrant crisis-Euroscepticism has grown more steeply, in particular the harder variety that opposes European integration per se rather than seeking reform of the European Union. ${ }^{40}$ The issues that appear most regularly to

35 See Ian Down and Carole J. Wilson, From 'Permissive Consensus' to 'Constraining Dissensus': A Polarizing Union?, 43 Acta Politica 26, 46 (2008).

36 For an important early paper, see generally Paul Taggart, A Touchstone of Dissent: Euroscepticism in Contemporary Western European Party Systems, 33 Eur J Polit Rsrch 363 (1998).

37 See Aleks Szczerbiak and Paul Taggart, Opposing Europe: Party Systems and Opposition to the Union, the Euro and Europeanisation *6-8 (Sussex European Institute Working Paper No 36, Oct 2000), archived at http://perma.cc/SQ7A-86GT. For a challenge to the hard/soft classification, see Petr Kopecky and Cas Mudde, Two Sides of Euroscepticism: Party Positions on European Integration in Central Europe, 3 EU Polit 297, 300 (2002).

38 See Maurits J. Meijers, Radical Right and Radical Left Euroscepticism: A Dynamic Phenomenon *6-7 (Jacques Delors Institut Berlin, Apr 7 2017), archived at http://perma.cc/F4Y4-RCWY.

39 See Erika J. van Elsas, Armen Hakhverdian, and Wouter van der Brug, United against a Common Foe? The Nature and Origins of Euroscepticism among Left-Wing and Right-Wing Citizens, 39 W Eur Polit 1181, 1186 (2016).

40 For some of the media commentary on the results of the 2014 European Parliament elections, see Eurosceptic 'Earthquake' Rocks EU Elections (BBC, May 26, 2014), archived 
underpin Euroscepticism today are an overall objection to the dilution of national sovereignty and a belief that freer transnational economic exchange in general and immigration in particular are exacerbating economic insecurity and cultural disruption. At the same time, it seems that the issue of support for (or opposition to) European integration emerged, like globalism versus nationalism, as a new and distinct social cleavage that has not easily been internalized or prioritized by traditional political parties whose core programs did not adapt to reflect its salience. ${ }^{41}$ New parties, on the other hand, arose rapidly in response to this emerging societal cleavage and adopted strong and sometimes extreme stances on it, and hence have attracted voters who were dissatisfied by the failure of traditional and mainstream parties to reflect their views on the issue. ${ }^{42}$

The second development has been the gradual rise of the farright movement and far-right political parties across Europe. This resurgence, which has been taking place over a number of decades, has also generated an extensive academic literature, much of which seeks to understand how a political movement that was banished to the fringes after the defeat of Nazism following World War II has reemerged considerably strengthened in many European states and what the factors are which have led to its reemergence. ${ }^{43}$ Theories include the successful reframing of the far right that took place through the marriage of fervent nationalism presented as authentic civic values, ${ }^{44}$ with populist hostility

at http://perma.cc/JJ2C-4BGW. For an academic analysis, see Sarah B. Hobolt and Catherine de Vries, Turning against the Union? The Impact of the Crisis on the Eurosceptic Vote in the 2014 European Parliament Elections, 44 Elec Stud 504, 505 (2016).

41 See Liesbet Hooghe and Gary Marks, Cleavage Theory Meets Europe's Crises: Lipset, Rokkan, and the Transnational Cleavage, 25 J Eur Pub Pol 109, 119-20 (2018).

42 For an analysis of the 2014 European Parliament elections in particular, when Eurosceptical parties won significant support, see Oliver Treib, The Voter Says No but Nobody Listens: Causes and Consequences of the Eurosceptic Vote in the 2014 European Elections, 21 J Eur Pub Pol 1541, 1543-46 (2014).

43 For a few samples, see generally Roger Eatwell, The Rebirth of the 'Extreme Right' in Europe?, 53 Parliamentary Aff 407 (2000); John W.P. Veugelers, A Challenge for Political Sociology: The Rise of Far-Right Parties in Contemporary Western Europe, 47 Current Sociology 78 (Oct 1999); Jens Rydgren, Is Extreme Right-Wing Populism Contagious? Explaining the Emergence of a New Party Family, 44 Eur J Polit Rsrch 413 (2005). See also Cas Mudde, Three Decades of Populist Right Parties in Europe: So What?, 52 Eur J Polit Rsrch 1, 8 (2013) (warning of the effect that the far right would have on the political spectrum and predicting that it would not be destined to remain in opposition, but rather would increasingly influence the policy agenda).

44 See Daphne Halikiopoulou, Steven Mock, and Sofia Vasilopoulou, The Civic Zeitgeist: Nationalism and Liberal Values in the European Radical Right, 19 Nations \& Nationalism 107, 109 (2013). 
against the establishment and anti-immigrant sentiment, as well as the far right's poaching of the economic policies of the socialdemocrat left, including a shift toward embracing redistributive welfare policies (albeit for citizens only) and against policies of austerity. ${ }^{45}$

The third relevant trend is the turn against so-called neoliberal capitalism. ${ }^{46}$ Unlike the other two trends described above, this development began as a clearly left-wing movement, spurred by intellectual critiques of capitalism and the global economic order from writers like Professor Noam Chomsky, Susan George, Naomi Klein, and Professor Noreena Hertz, as well as former Washington insiders like Professor Joseph Stiglitz. ${ }^{47}$ The accompanying antiglobalization movement saw street protests against the World Trade Organization meeting in Seattle in 1999 spread to various parts of the world, including to Europe, where organizations like Association for the Taxation of Financial Transactions and Aid to Citizens (ATTAC) ${ }^{48}$ and the European Social Forum were established. ${ }^{49}$ However, with the onset of the global financial crisis and the Euro crisis, the backlash against the policies of austerity promoted by international organizations

45 On the recent borrowing by far-right parties of the economic welfarist and antiausterity policies of the left, see Audrey Sheehy, The Rise of the Far Right (Harvard Political Review, Feb 11, 2017), archived at http://perma.cc/T4GE-WH2H ("The far right is competing directly with the left on economic policy; however, the far right is exploiting the rift in the left."); Bojan Bugaric, Europe's Nationalist Threat (American Prospect, May 18, 2016), archived at http://perma.cc/J39W-4FV4 (blaming the rise of populist right-wing parties on the moderate parties' embrace of fiscal austerity). For a discussion of the relationship between economic insecurity and the rise of far-right parties, see generally Tim Vlandas and Daphne Halikiopoulou, Why Far Right Parties Do Well at Times of Crisis: The Role of Labour Market Institutions (European Trade Union Institute, July 2017), archived at http://perma.cc/2FG2-5BLF; Daphne Halikiopoulou, Why Are Far Right Parties Increasing Their Support across Europe? A Note on the French Election (HuffPost UK, Apr 21, 2017), archived at http://perma.cc/MH38-EXUM.

46 See generally David Harvey, A Brief History of Neoliberalism (Oxford 2005).

47 See generally Noam Chomsky, Profit over People: Neoliberalism and Global Order (Seven Stories 1999); Susan George, A Short History of Neoliberalism (Transnational Institute, Mar 24, 1999), archived at http://perma.cc/P9Y7-ARK6; Naomi Klein, This Changes Everything: Capitalism vs. the Climate (Simon \& Schuster 2014); Noreena Hertz, The Silent Takeover: Global Capitalism and the Death of Democracy (HarperBusiness 2003); Joseph E. Stiglitz, Globalization and Its Discontents (Norton 2003).

48 Overview (ATTAC), archived at http://perma.cc/V39W-34J7. ATTAC describes itself as "an international organization involved in the alter-globalization movement. [It] oppose[s] neo-liberal globalization and develop[s] social, ecological, and democratic alternatives so as to guarantee fundamental rights for all." It is best known for its advocacy of a so-called Tobin tax on international financial movements.

49 See Élise Féron, Anti-globalization Movements and the European Agenda: Between Dependence and Disconnection, 17 Eur J Soc Sci Rsrch 119, 120 (2004). 
like the International Monetary Fund (IMF) and the European Union itself saw critiques of the global economic order spread well beyond their origins on the left. As already noted, opposition to austerity policies in various European states has more recently come from all sides of the political spectrum and not just from the left. Right-wing and far-right parties in countries including France, the Czech Republic, Hungary, Poland, and Slovakia have adopted antiglobalist and economically nationalist policies that reject austerity and promote statist economic policies centered on welfare. ${ }^{50}$ A relationship between economic insecurity and a rejection of globalism, including freer trade and open borders (and including rejection of the European Union), has been suggested by a number of studies, ${ }^{51}$ even though cultural factors are also clearly relevant to the rise in nationalist sentiment in the European Union and elsewhere and to the rejection of internationalism. ${ }^{52}$ Nevertheless, even if the Euro crisis helped to fuel support for extreme right-wing parties, it seems clear that the resurgence and growth of these parties significantly predated the economic crisis in the European Union, and that public hostility toward immigration was a more salient factor than economic disruption and austerity. ${ }^{53}$

How should the relationship between these three sets of developments be understood, when seeking to address the question whether European integration has fueled the rise of illiberal authoritarianism? It seems clear that Euroscepticism has been a feature of politics in many European states, most obviously since the time of the Maastricht Treaty in 1993, and that opposition to the European Union has been growing steadily in many member

50 See Ronald F. Inglehart and Pippa Norris, Trump, Brexit and the Rise of Populism: Economic Have-Nots and Cultural Backlash *2 (Harvard Kennedy School Research Working Paper 16-026, Aug 2016), archived at http://perma.cc/GTK6-LG9A.

51 See, for example, Brian Burgoon, Inequality and Anti-globalization Backlash by Political Parties *14 (GINI Discussion Paper 14, Oct 2011), archived at http://perma.cc/BU6V-Y2JL; Anabel Kuntz, Eldad Davidov, and Moshe Semyonov, The Dynamic Relations between Economic Conditions and Anti-immigrant Sentiment: A Natural Experiment in Times of the European Economic Crisis, 58 Intl J Comp Sociology 392, 396 (2017). See also generally Vlandas and Halikiopoulou, Why Far Right Parties Do Well at Times of Crisis (cited in note 45).

52 See Inglehart and Norris, Trump, Brexit and the Rise of Populism at *27 (cited in note 50).

53 See Matthew Goodwin, Europe's Far Right: Don't Blame the Eurozone Crisis (Chatham House, Aug 15, 2012), archived at http://perma.cc/E6X4-6MCS; Emily Schultheis, A New Right-Wing Movement Rises in Austria (The Atlantic, Oct 16, 2017), archived at http://perma.cc/U7Y8-RKYZ (discussing how the far right in Austria managed to succeed in recent elections based on its anti-immigration platform). 
states for over two decades, rising through the more recent period of the refugee crisis and economic crisis. However, it would not be correct to infer that opposition to the European Union, or Euroscepticism, provides the main explanation-or even a dominant explanation-for the rise and revival of the far right across Europe. Any easy inference of this kind is challenged by the evidence that the resurgence of the right in Europe has been a gradual trend unfolding over more than three decades, with origins and causes well before the rise of Euroscepticism or opposition to the EU form of supranational governance had emerged. ${ }^{54}$ At the same time, it is undeniable that far-right parties have exploited and benefited from the fact that mainstream parties across the European continent have been overwhelmingly supportive of European integration and that the growing nationalismglobalism and national-European cleavages were not reflected adequately in the programs or policies of most of the traditional parties.

Along these lines, Professor Renee Buhr has argued that extremist parties benefited from a social backlash against European integration in the post-Maastricht period, at a stage when virtually all mainstream parties supported European integration. ${ }^{55}$ In offering themselves as parties that provided a voice for concerns about EU integration, these parties of the extreme right (and some on the left that opposed EU membership or EU policies) benefited electorally from the pro-integration consensus of the mainstream parties. Further, the growing critique of neoliberal capitalism, which originated on the left of the political spectrum but spread to the right in particular after the global financial crisis, provided further grist to far-right parties that combine opposition to the European Union and its single-market policies with economic and cultural nationalism. Hence the later and stronger backlash after 2009, in the wake of the Euro crisis and the broader economic crisis, against the market-liberalization and austerity policies of the European Union brought further support for far-right parties that also espoused and promoted populist illiberalism.

A final point worth making is one that was raised by Professor Peter Mair in 2006 when he suggested that Euroscepticism was

54 See Eatwell, 53 Parliamentary Aff at 408-09 (cited in note 43); Mudde, 52 Eur J Polit Rsrch at 4 (cited in note 43).

55 See Renee L. Buhr, Seizing the Opportunity: Euroscepticism and Extremist Party Success in the Post-Maastricht Era, 47 Govt \& Opposition 544, 550 (2012). 
something more than opposition to or skepticism toward the European Union and its policies, but might be a form or species of a more general trend that he called "polity-scepticism." ${ }_{56} \mathrm{By}$ this he meant that Euroscepticism was not so much an objection to the European Union as a form of regional integration, but actually seemed to be part of a broader democratic malaise manifesting itself in a growing lack of political engagement by citizens, a disenchantment with politics and representative democracy, and a lack of electoral or party engagement. ${ }^{57}$

To conclude, while there is clearly a relationship between opposition to the European Union, Euroscepticism, and a growth in support for far-right parties that promote or espouse authoritarian illiberalism, it would be overstating the evidence to suggest that European integration is responsible for the resurgence of such parties, and that supranational governance is thus proving to be a challenge to liberal constitutionalism. Nevertheless, Euroscepticism, together with a critique of global capitalism and economic neoliberalism (which the European Union is considered by at least a significant portion of its citizens to exemplify), and a more general disaffection with the political system that has been directed against the European Union as well as against mainstream domestic politics, has helped authoritarian and illiberal parties to strengthen and expand.

Quite apart from the question of whether opposition to or skepticism toward the European Union has fueled the rise in support for illiberal authoritarianism and the far right, however, is the more general question whether there is something in the project and structure of European integration itself that poses a challenge to liberal constitutionalism.

\section{IS THE PROJECT OF SUPRANATIONAL EUROPEAN INTEGRATION A CHALLENGE TO LIBERAL CONSTITUTIONALISM?}

Has European integration undermined liberal constitutionalism? Or, put more positively, is there something about the project of supranational governance established by the European Union

\footnotetext{
56 See generally Peter Mair, Polity-Scepticism, Party Failings, and the Challenge to European Democracy (Netherland Institute for Advanced Study in the Humanities and Social Sciences Uhlenbeck Lecture 24, June 9, 2006), archived at http://perma.cc/6N65-SAJP.

57 Id at ${ }^{*} 6$.
} 
that in itself poses a challenge to liberal constitutionalism, understood in the terms described in the Symposium Introduction?58 To answer this question requires reflection on what the relationship of the European Union, considered as a form of supranational governance, is to liberal constitutionalism in general, and to national liberal constitutionalism in particular.

At least in its earliest form, when a draft treaty establishing a European Political Community was drawn up in 1952, 59 the project of European integration arguably resembled a continentwide experiment in liberal constitutionalism. Under the terms of the draft treaty there were to be political decisionmaking bodies modeled on national federal systems; a bill of rights in the shape of the recently drafted ECHR was to be integrated into the European political community; and the ECtHR in Strasbourg was to be given jurisdiction over disputes arising under the new treaty. ${ }^{60}$ This was an early federal vision for an integrated European continent with a liberal democratic constitution and system of government. As is well known, however, that vision did not survive the rejection of the European Defence Treaty by France in 1953, and with it the draft European Political Community also disappeared. ${ }^{61}$

As a consequence of the failed experiment with the European Defence Community and draft Political Community, the EEC, which was established some years later by the Treaty of Rome, was far from the fully fledged political community that had earlier been envisaged. The 1957 Treaty of Rome was deliberately circumscribed in its scope and ambition, limited largely to the establishment of a common market, in part to avoid the fate that had befallen the earlier attempts at European integration. ${ }^{62} \mathrm{Nev}$ ertheless, even in circumscribed form, the EEC reflected some of the embryonic elements of a liberal democratic political system. The EEC treaty included provision for a parliamentary assembly, which although not initially to be directly elected, contained a provision envisaging the introduction of direct elections at a later

\footnotetext{
58 See Ginsburg, Huq, and Versteeg, 85 U Chi L Rev at 239 (cited in note 9).

59 See generally Richard T. Griffiths, Europe's First Constitution: The European Political Community, 1952-1954 (Federal Trust 2000); Gráinne de Búrca, The Road Not Taken: The European Union as a Global Human Rights Actor, 105 Am J Intl L 649 (2011).

60 See de Búrca, 105 Am J Intl L at 654-55 (cited in note 59).

61 For a detailed history of France's role in this chain of events, see generally Rogelia Pastor-Castro, The Quai d'Orsay and the European Defence Community Crisis of 1954, 91 Hist 386 (2006).

62 See de Búrca, 105 Am J Intl L at 664-65 (cited in note 59).
} 
date. ${ }^{63}$ Nevertheless, the new supranational organs of governance - the Commission and the Council of Ministers-and the division of powers between them, did not amount to the kind of politically accountable and representative government to be found within most of the EU member states at the time. Further, while a reasonably strong Court of Justice was created to adjudicate on disputes under the treaty, there was no mention of human rights, and despite the provision for judicial review of acts of the European Community, access to judicial review for individuals was fairly limited through restrictive locus standi provisions. ${ }^{64} \mathrm{By}$ comparison with the earlier draft European Political Community treaty, any express reference to human rights or to the ECHR was omitted from the EEC treaty.

Over the decades that followed, in a set of developments that is by now well known, the European Parliament gradually became a directly elected body and eventually gained significant lawmaking powers in conjunction with the Council of Ministers. ${ }^{65}$ Around the same time the ECJ, after initial hesitation in a number of cases that unsuccessfully tried to introduce ideas of human rights from the German legal order into EU law, ${ }^{66}$ declared that fundamental rights were part of EU law as unwritten general principles of law, and this precipitated a period of gradual integration of human-rights provisions into the EU treaties and through ECJ case law. ${ }^{67}$ Almost forty years after the creation of the European Economic, Coal and Steel, and Atomic Energy communities, the Maastricht Treaty transformed the European Communities into the European Union. This was a union with its own currency and a powerful lawmaking parliament, a union that introduced a form of European citizenship for all member-state nationals. ${ }^{68}$ The new TEU introduced by the Maastricht Treaty

63 For an account of the influence of federal ideas on the early period of European integration, see Sergio Pistone, The Union of European Federalists: From the Foundation to the Decision on Direct Election of the European Parliament (1946-1974) 194-95 (Giuffrè Editore 2008).

64 See Eric Stein and G. Joseph Vining, Citizen Access to Judicial Review of Administrative Action in a Transnational and Federal Context, 70 Am J Intl L 219, 222-24 (1976).

65 For a general history of this process, see Francis Jacobs, Richard Corbett, and Michael Shackleton, The European Parliament 13-16 (Cartermill 3d ed 1995).

66 See generally Manfred A. Dauses, The Protection of Fundamental Rights in the Community Legal Order, 10 Eur L Rev 398 (1985).

67 For discussion of this development by the ECJ, see de Búrca, $105 \mathrm{Am} \mathrm{J}$ Intl L at 668 (cited in note 59).

68 The Maastricht Treaty introduced TEU Article 8 (now known as Article 20 of the Treaty on the Functioning of the European Union since the coming into force of the Lisbon 
contained prominent references to the ECHR and to the general principles of EU law. In other words, even while the language of statehood continued to be consciously avoided, ${ }^{69}$ the European Union began to emerge as a real political union and to resemble a system of liberal constitutionalism on a European scale.

A debate on whether the European Union had a constitution, or could be considered as a constitutional order, which until then had been the preserve of a few academic lawyers, began in earnest after the Maastricht Treaty, ${ }^{70}$ and continued apace until the 2004 decision of the heads of state and government of the European Union to establish a convention tasked with the drafting of a treaty establishing a constitution for Europe. ${ }^{71}$ The drafting of this treaty establishing a constitution for Europe proved in retrospect to be the high point of European constitutionalism thus far, and the rejection of the treaty by popular referendum in the Netherlands and France in 2005 signaled the end of the explicit constitutional vision for the European Union. ${ }^{72}$ Such a defeat for the treaty by way of a popular vote in two of the founding states of the European Union meant that the formal EU constitutional project was abandoned and the treaty remained unratified. Nevertheless, after a number of years of reflection and discussion among the EU heads of state and government, the bulk of the draft constitutional treaty, albeit shorn of the symbolic constitutional provisions that were taken to have been offensive to the people of France and the Netherlands, was enacted into law as the Lisbon Treaty in 2009.73

Treaty in 2010), which provides that "Citizenship of the Union is hereby established. Every person holding the nationality of a Member State shall be a citizen of the Union." See TEU Art 20, $55 \mathrm{~J}$ EU C326 at 20-21.

69 For a debate on the pros and cons of a vision of EU "statehood," see generally G. Federico Mancini, Europe: The Case for Statehood, 4 Eur L J 29 (1998); J.H.H. Weiler, Europe: The Case against the Case for Statehood, 4 Eur L J 43 (1998).

70 See generally, for example, Jean-Claude Piris, Does the European Union Have a Constitution? Does It Need One? (Jean Monnet Center, 2000), archived at http://perma.cc/X47M-XJL9; Neil Walker, EU Constitutionalism in the State Constitutional Tradition (EUI Law Working Paper No 2006/21, 2006), archived at http://perma.cc/Z6UH-WLSL.

71 See generally Treaty Establishing a Constitution for Europe, 47 J EU C310 (2004).

72 See Rudolf Streinz, The European Constitution after the Failure of the Constitutional Treaty, 63 Zeitschrift für Öffentliches Recht 159, 170 (2008).

73 See generally Jan Wouters, Luc Verhey, and Philipp Kiiver, eds, European Constitutionalism beyond Lisbon (Intersentia 2009). See also Gráinne de Búrca, Reflections on the EU's Path from the Constitutional Treaty to the Lisbon Treaty *11 (Jean Monnet Working Paper No 3/2008, June 2008), archived at http://perma.cc/9UEF-64GE. 
While academic and public debate as to whether the European Union had or needed a constitution abated for some time after the failure of the constitutional treaty, one of the underlying questions from that earlier debate remained particularly salient: Was the European Union in fact a constitutional order? One prominent strand of scholarly literature following the Maastricht Treaty centered around a debate about whether or not the European Union has a demos. ${ }^{74}$ The gist of the "no demos" argument was that because the European Union did not itself have a demos (a sufficiently unified people), it lacked the preconditions for genuine democratic legitimacy as a polity. ${ }^{75}$ This view was contested, and various competing theories of EU democracy-including the idea that the European Union is best considered as a "demoicracy"were advanced. ${ }^{76}$ And yet, despite the ongoing debate about the EU's democratic legitimacy and democratic deficit, 77 it seemed by the time of the enactment of the Lisbon Treaty that the European Union had come to include most of the other main elements of a liberal constitutional system. It has a written constitutionlike set of treaties, including a Charter of Fundamental Rights. The ECJ conducts rights-based judicial review, and the European Parliament is directly elected. The treaties include a commitment

74 See generally, for example, Mette Jolly, A Demos for the European Union?, 25 Polit 12 (2005).

75 See J.H.H. Weiler, Does Europe Need a Constitution? Demos, Telos and the German Maastricht Decision, 1 Eur L J 219, 222-24 (1995).

76 See generally, for example, Vivien A. Schmidt, Democracy and Legitimacy in the European Union Revisited: Input, Output and 'Throughput,' 61 Polit Stud 2 (2013); Kalypso Nicolaïdis, The Idea of European Demoicracy, in Julie Dickson and Pavlos Eleftheriadis, eds, Philosophical Foundations of European Union Law 247 (Oxford 2012).

77 For one of the classic debates on the European Union's "democratic deficit," see generally Andreas Føllesdal and Simon Hix, Why There Is a Democratic Deficit in the EU: A Response to Majone and Moravcsik, $44 \mathrm{~J}$ Common Mkt Stud 533 (2006); Giandomenico Majone, Europe's 'Democratic Deficit': The Question of Standards, 4 Eur L J 5 (1998); Andrew Moravcsik, The Myth of Europe's "Democratic Deficit," 43 Intereconomics 331 (2008). For some more recent contributions, see generally Antoine Vauchez, Democratizing Europe (Palgrave 2016); Richard Bellamy and Sandra Kröger, Domesticating the Democratic Deficit? The Role of National Parliaments and Parties in the EU's System of Governance, 67 Parliamentary Aff 437 (2012). Recently the debate on the European Union's "democratic deficit" has moved beyond the realm of academic scholarship and into the mainstream media. See, for example, Jennifer Rankin, Is the EU Undemocratic? (The Guardian, June 13, 2016), archived at http://perma.cc/T8W8-EZA4; How to Address the EU's Democratic Deficit (The Economist, Mar 23, 2017), online at http://www .economist.com/news/special-report/21719196-institutions-need-reform-how-address-eus -democratic-deficit (visited Oct 16, 2017) (Perma archive unavailable); Amanda Taub, The E.U. Is Democratic. It Just Doesn't Feel That Way (NY Times, June 29, 2016), online at http://www.nytimes.com/2016/06/30/world/europe/the-eu-is-democratic-it-just-doesnt -feel-that-way.html?_r=1 (visited Oct 16, 2017) (Perma archive unavailable). 
to the rule of law (including a rule-of-law mechanism for disciplining states), ${ }^{78}$ and power is distributed across the various institutions in such a way as would appear to prevent any one institution from dominating or concentrating power. Nevertheless, despite parliamentary elections, a powerful European Parliament, democratically elected representatives in the Council of Ministers, a legally enshrined principle of transparency, a strong EU court, and various layers of legal and constitutional rights protection, the European Union still lacks real responsiveness to the preferences of its citizens. ${ }^{79}$

Hence, as far as its democratic credentials are concerned, there is an ongoing debate about the quality of democracy in the European Union, focusing particularly on whether there is a European people and on the lack of adequate responsiveness to citizens within the EU system of governance. At the same time, however, and despite this debate about its democratic responsiveness, the EU political system nonetheless includes and embodies many of the key features of liberal constitutionalism. Indeed the European Union formally insists, under Articles 2, 7, and 49 of the TEU, on a commitment on the part of all of its member states to human rights, democracy, and the rule of law, and has wrestled in recent years with the question of how it should tackle democratic backsliding in Hungary and Poland. ${ }^{80}$ In other words, despite contestation over the quality of democracy, the European Union in the main is constructed as, and contains the main elements of, a liberal constitutional political system. Why then pose the question whether the structure and functioning of European supranational governance poses a risk to liberal constitutionalism? If the European Union is founded on the values of democracy, human rights, and the rule of law, and seeks to condition accession to the European Union on adherence to these values, how can it pose a challenge to them?

78 See TEU Art 7, 55 J EU C326 at 19-20; Commission to the European Parliament and the Council, A New EU Framework to Strengthen the Rule of Law *5 (Mar 19, 2014), archived at http://perma.cc/Z77X-7RWG.

79 For an analysis of the issues underlying the European Union's lack of political responsiveness, see generally Simon Hix, What's Wrong with the European Union and How to Fix It (Polity 2008).

80 Article 2 reads, "The Union is founded on the values of respect for human dignity, freedom, democracy, equality, the rule of law and respect for human rights, including the rights of persons belonging to minorities," with Articles 7 and 49 providing for cooperative enforcement of these terms. TEU Arts 2, 7, 49, $55 \mathrm{~J}$ EU C326 at 17, 19-20, 43. 
One main reason is the risk that, whatever the strength and quality of its own constitutional features and institutional structures, the functioning of the European Union may nonetheless undermine rather than support or enhance the democratic constitutional systems of member states. ${ }^{81}$ There are a number of different if related dimensions of this risk. A first is the impact to date of the articulation by the ECJ of a broad and fairly uncompromising principle of supremacy of EU law over national law. One particular aspect of this concern that has recently been articulated is the issue of national identity, and the question whether European integration in general and the operation of the supremacy principle in particular have undermined important aspects of national constitutional identity. A second concern is the general trend toward "executive dominance" in the European Union and its exacerbation by the technocratic and managerial workings of the EU supranational institutions. Thirdly, there is the impact of the European Union's prioritization of its project of economic liberalization over other domestic and transnational goals, and particularly its impact on the functioning of national social democracy.

Beginning with the principle of the supremacy, the idea of the primacy of EU law over national law was first introduced by the ECJ in the early $1960 \mathrm{~s},{ }^{82}$ and gradually took hold across the European Union. ${ }^{83}$ From as early as 1970, the court insisted on the supremacy of EU law over all provisions of national law of whatever rank, including provisions of the national constitution. ${ }^{84}$ Various aspects of the supremacy principle were challenged from the outset, with particular concern being expressed over the ECJ's assertion that any binding and directly effective provision of EU law-whatever its content-must in the interests of uniformity of EU law take precedence over any provision of national constitutional law, even over basic constitutional rights. This claim has generated controversy and pushback from domestic constitutional courts ever since the first Solange judgment of the

81 See Dieter Grimm, The Constitution of European Democracy 97-101 (Oxford 2017).

82 The foundational trio of cases introducing and articulating the scope of the supremacy of EU law over domestic law are Costa v ENEL, [1964] ECR 585; Internationale Handelsgesellschaft mbH $v$ Einfuhr- und Vorratsstelle für Getreide und Futtermittel, [1970] ECR 1125; and Amministrazione delle Finanze dello Stato v Simmenthal SpA, [1978] ECR 629.

83 See generally Karen J. Alter, Establishing the Supremacy of European Law: The Making of an International Rule of Law in Europe (Oxford 2001).

84 See generally Internationale Handelsgesellschaft, [1970] ECR 1125. 
Bundesverfassungsgericht, the German Constitutional Court, in $1974 .{ }^{85}$ In that ruling, the court declared that the part of the constitution dealing with basic rights was an inalienable essential feature of German constitutional law and that given the state of the European Union at the time (when it was still the EEC with fewer developed features of liberal constitutionalism, lacking a directly elected parliament or an entrenched bill of rights), the guarantees of basic rights in the German constitution would prevail over EU law in the event of conflict. ${ }^{86}$

And even though, as described above, the European Union has developed significantly since that time and currently has a powerful directly elected parliament as well as a binding Charter of Fundamental Rights, the controversy over the ECJ's claim that EU law must prevail over domestic constitutional rights has continued, and a series of robust rulings have been given by a range of national constitutional courts, including the Bundesverfassungsgericht, articulating limits to the operation of the principle of supremacy of EU law. Cases-such as the Melloni reference to the ECJ from the Spanish Constitutional Court involving a conflict between the provisions of the EU Arrest Warrant and the right to a fair trial in the Spanish Constitution, ${ }^{87}$ and the Taricco reference from the Italian Constitutional Court involving a conflict between the principle of legality in Italian constitutional law and EU value-addedtax law ${ }^{88}$ - demonstrate that the kinds of concerns expressed in Solange I retain their significance. In other words, national courts and other constituencies are concerned that EU law may undermine domestic constitutional law by failing to respect the specificity or importance of particular rights and protections guaranteed as part of national constitutional law.

A related and more recently articulated aspect of the concern over the operation of the supremacy principle is the question whether it has weakened or undermined the national constitutional identity of EU member states. Liberal constitutionalism has until now been developed within the nation-state context, as a framework for the functioning of a healthy democratic political system, and national constitutions generally purport to embody or articulate elements of national identity. The European Union,

85 See generally Internationale Handelsgesellschaft mbH $v$ Einfuhr- und Vorratsstelle für Getreide und Futtermittel, [1974] 2 CMLR 540 (BVerfG) ("Solange I").

86 Id at 550.

87 See generally Melloni v Ministerio Fiscal, [2013] 2 CMLR 43 (ECJ).

88 See generally Taricco, [2016] 1 CMLR 21 (ECJ). 
however, is not a nation-state, and although it has effectively established a continent-wide system of liberal constitutionalism, its democratic system remains relatively weak and noncontestatory, and its identity is complex, contested, and polyphonous. ${ }^{89}$ Political and popular concern about the process of European integration undermining or weakening national identity, ${ }^{90}$ including national constitutional identity, resulted in the addition in 2010 of a new provision by the Lisbon Treaty (and previously by the unratified Constitutional Treaty) to the TEU. Article 4(2) of the TEU now provides that the European Union "shall respect the equality of Member States before the Treaties as well as their national identities, inherent in their fundamental structures, political and constitutional, inclusive of regional and local self-government." ${ }_{11}$

This provision has already generated a voluminous academic literature, with many applauding the move to provide treatybased recognition and protection for national constitutional identities..$^{92}$ Others, however, have noted the paradoxical risk that this provision may be invoked by governments like Hungary's that are deliberately undermining liberal constitutional safeguards within their own political systems, and using the new provision in Article 4(2) to ward off attempts by the European Union or the ECJ to prevent them from doing so. ${ }^{93}$ Hence the impact of

89 See Janie Pélabay, Kalypso Nicolaïdis, and Justine Lacroix, Echoes and Polyphony: In Praise of Europe's Narrative Diversity, in Justine Lacroix and Kalypso Nicolaïdis, eds, European Stories: Intellectual Debates on Europe in National Contexts 334, 335 (Oxford 2010).

90 An earlier provision introduced by the Maastricht Treaty had provided that "the Union shall respect the national identities of its Member States," Maastricht Treaty Title I, Art F, 35 J EU C191 at 5, but had not referred to national constitutional identity. The constitutional aspect of identity was added by the Lisbon Treaty. See Treaty of Lisbon Art 1, § 5, 50 J EU C306 1, 12 (2007).

91 TEU Art 4(2), 55 J EU C326 at 18 (emphasis added).

92 See Armin von Bogdandy and Stephan Schill, Overcoming Absolute Primacy: Respect for National Identity under the Lisbon Treaty, 48 Common Mkt L Rev 1417, 1418 (2011).

93 The Hungarian Constitutional Court invoked the idea of national constitutional identity in a judgment in 2016, in relation to a decision of the European Union on the relocation of asylum seekers. See $A B$ on the Interpretation of Article E)(2) of the Fundamental Law, Decision 22/26. (XII. 5.), slip op at 16-17 (Hungary Const Ct Nov 30, 2016), archived at http://perma.cc/36V6-AKEU. See also Gábor Halmai, National(ist) Constitutional Identity? Hungary's Road to Abuse Constitutional Pluralism *10-11 (EUI Working Paper 2017/08, Aug 2017), archived at http://perma.cc/MU5T-C8BB. See also generally Theodore Konstadinides, Constitutional Identity as a Shield and as a Sword: The European Legal Order within the Framework of National Constitutional Settlement, 13 Camb Yearbook Eur Legal Stud 195 (2011); Alejandro Saiz Arnaiz and Carina Alcoberro Llivina, eds, National Constitutional Identity and European Integration (Intersentia 2013). For a distinc- 
the European Union on national constitutional identity, insofar as the question is whether it is likely to undermine liberal constitutionalism rather than to bolster or support it, seems not to be a straightforwardly negative one. One way of expressing the relationship between the European Union and national constitutional identity is to accept that European integration has challenged national constitutional identity, but not necessarily in a negative way, and that it both supports the fundamental premises of liberal constitutionalism while at the same time sometimes challenging aspects of the way in which liberal constitutionalism is interpreted in specific national contexts.

A second aspect of the concern that the European Union is posing a challenge to domestic constitutional democracy relates to the problem of executive dominance. The suggestion that there may be a trade-off between democracy and transnational or global governance was made in a different context in 1971 by Karl Kaiser. ${ }^{94}$ While transnational cooperation and interdependenceincluding in the EU context-has been a strongly positive force in all sorts of ways, the question is whether such interdependence, even if it has reduced war and increased human welfare in many ways, might also be linked with a weakening in the quality of existing state-based democratic governance. In the EU context, it has been argued that the process of integration has given rise to the gradual dominance of the executive branches, and has weakened the role, cogency, and effectiveness of domestic democratic mechanisms and systems. ${ }^{95}$ Some have described the phenomenon more sharply as "collusive delegation" by national governments to transnational bodies and organizations, enabling governments and executives to work collectively at the European and international level to achieve their goals in ways that deliberately bypass national democratic institutions, and increasing concern that European (and global) governance institutions may be weakening or

tion between national identity and constitutional identity, see Elke Cloots, National Identity, Constitutional Identity, and Sovereignty in the EU, 45.2 Netherlands J Legal Phil 82, 84-86 (2016).

94 See generally Karl Kaiser, Transnational Relations as a Threat to the Democratic Process, 25 Intl Org 706 (1971). For a more recent discussion of some of the tensions between international legal governance and democracy, see generally J.H.H. Weiler, The Geology of International Law-Governance, Democracy and Legitimacy, 64 ZaöRV 547 (2004). For the opposite argument that multilateral and international institutions may enhance rather than undermine domestic democracy, see Robert O. Keohane, Stephen Macedo, and Andrew Moravcsik, Democracy-Enhancing Multilateralism, 63 Intl Org 1, 4 (2009).

95 See, for example, Deirdre Curtin, Challenging Executive Dominance in European Democracy, 77 Mod L Rev 1, 16-17 (2014). 
undermining domestic democratic systems. ${ }^{96}$ It might even be argued that moral hazard is built into the establishment of many international institutions, in that they allow or encourage domestic policymakers to bypass domestic democratic institutions and disincentivize domestic democratic bodies from robust engagement with policies that are perceived to be within the purview of transnational or foreign policy actors. ${ }^{97}$

A third strand of the critique that the European Union is undermining domestic constitutional democracy has been articulated for some years since the Maastricht Treaty, in particular by a group of prominent German scholars including Professors Fritz Scharpf, Claus Offe, Wolfgang Streeck, and Christian Joerges, who focus on the way in which the EU treaties have promoted a particular ordoliberal vision. They argue that the EU promotion of transnational economic integration has prioritized "negative" integration, the dismantling of regulatory barriers to interstate trade, over positive integration to pursue welfare goals and protect social rights, and that this set of priorities has effectively been written into EU treaties in a way that is difficult to change and that overrides key domestic institutions and choices. ${ }^{98} \mathrm{~A}$ central aspect of their concern is that the European Union lacks the institutional and social resources to pursue an active and adequate Europe-wide social policy, and yet through its deregulatory and monetary policies has weakened the capacity of national social democracies to fulfill their goals and undermined the functioning of those democracies. After the onset of the Euro crisis in 2009, the expansion of technocratic governance and the imposition of austerity policies by the European Union and the IMF, which have had such profoundly negative social effects on debtor countries and particularly on Greece, added powerful grist and a

96 See Klaus Dieter Wolf, The New Raison d'État as a Problem for Democracy in World Society, 5 Eur J Intl Rel 333, 335-36 (1999). For an application of this theory to EU governance, see Mathias Koenig-Archibugi, International Governance as New Raison d'Etat? The Case of the EU Common Foreign and Security Policy, 10 Eur J Intl Rel 147 (2004).

$97 \quad$ I am grateful to Aziz Huq for this point.

98 See, for example, Fritz W. Scharpf, The Asymmetry of European Integration, or Why the EU Cannot Be a "Social Market Economy" *12 (KFG Working Paper No 6, Sept 2009), archived at http://perma.cc/NJU5-FMAC; Claus Offe, The European Model of "Social" Capitalism: Can It Survive European Integration?, 11 J Polit Phil 437, 467 (2003); Christian Joerges, Rechtsstaat and Social Europe: How a Classical Tension Resurfaces in the European Integration Process, 9 Comp Sociology 65, 70-72 (2010). See also generally Steffen Lehndorff, ed, A Triumph of Failed Ideas: European Models of Capitalism in the Crisis (ETUI 2012). 
new dimension to these critiques. ${ }^{99}$ The fact that fundamental economic rules-whether free-movement and competition rules, or excessive deficit provisions-are written into the EU treaties and become effectively obligatory for member states means that the space for domestic politics and contestation over such issues is more or less closed. While this concern may seem to be more about the impact of EU economic integration goals on domestic welfare policies rather than its impact on liberal constitutionalism, the fact that social rights are written into the constitutions of some member states, or that the welfare state or social democracy is an important component of the constitutional system of certain member states (as in the German constitution's guarantee of a democratic and social federal state) brings the two issues closer together.

\section{CONCLUSION}

This Essay began by reflecting on the relationship between the EU system of supranational governance, the rise of illiberal populism and authoritarianism, and the decline of liberal constitutionalism. Having considered whether the Brexit votewhich has been widely seen as a kind of populist revolt against a sovereignty-constraining European Union-was a part of this trend, I concluded that while certain elements underpinning the vote to leave the European Union reflected illiberal or authoritarian tendencies, the Brexit decision overall cannot be said to represent a move against liberal constitutionalism or in favor of illiberal authoritarianism. Similarly, although the spread of Euroscepticism to which the deepening and expansion of European integration gave rise has benefited extreme right-wing movements and parties across Europe, the reemergence and growth of the far right in various European states had begun well before strong anti-EU sentiment became prevalent. Nevertheless, as elaborated in the previous Part, even though the European Union is itself now in many respects firmly committed to liberal constitutionalism and to promoting the spread of democracy and constitutionalism, the functioning of EU supranational governance has certainly challenged national constitutional institutions

\footnotetext{
99 See generally Wolfgang Streeck, Markets and Peoples: Democratic Capitalism and European Integration, 73 New Left Rev 63 (Jan-Feb 2012). For a more developed version of this argument, see generally Wolfgang Streeck, Buying Time: The Delayed Crisis of Democratic Capitalism (Verso 2014).
} 
and norms in various ways. In particular, the inadequate responsiveness of EU governance institutions to citizens, the judicial declaration of unconditional primacy of all EU laws over national constitutional rights, the growth of executive dominance and technocratic governance, and the bypassing of domestic parliamentary and democratic institutions, as well as the weakening of state-based social democracy through the European Union's prioritization of deregulatory and economically neoliberal policies (highlighted prominently during the management of the Euro crisis) have been ongoing sources of concern.

Are these challenges to national liberal constitutionalism intrinsic to the process of EU supranational governance, and an inevitable consequence of the project of transnational integration? I suggest that while some of the challenges posed by EU supranational governance to national constitutionalism are indeed intrinsic to the process of European integration, certain aspects of this challenge are not necessarily a negative development. In particular, the challenges posed to national constitutionalism and national constitutional identity by Europe-wide liberal constitutionalism can and in some cases have created a constructive dialogue between the European Union and national judiciaries about the meaning and scope of a given constitutional right, taking into account the distinctive transnational context of the European Union. For some of the other challenges, however, and in particular the risk of executive dominance and unresponsive technocratic governance, there is a real need for reflection and reform at both the level of national government and at the EU level.

As far as the challenge of unconditional and judicially determined EU supremacy over domestic constitutional rights is concerned, a great deal has already been written about constitutional pluralism in the European Union and the ability of national constitutional courts not to follow the rulings of the ECJ when they are considered to threaten or undermine fundamental provisions of the domestic constitutional order. ${ }^{100}$ At the same time, the development of greater trust between the ECJ and domestic constitutional courts would help in handling those cases in which an apparent conflict between EU law and national constitutional rights is at stake. Greater trust could encourage appropriate deference on the part of the ECJ in those cases in which an important

100 For book-length treatments, see generally Klemen Jaklic, Constitutional Pluralism in the EU (Oxford 2014); Matej Avbelj and Jan Komárek, eds, Constitutional Pluralism in the European Union and Beyond (Hart 2012). 
national constitutional right is at issue rather than being instrumentally invoked to avoid the application of EU law; thus, the ECJ should pay close attention to the domestic values at stake and the reason for the domestic court's interpretation of a particular provision. It should also, however, help national constitutional courts to accept that membership in the European Union has entailed a change to the national constitutional order and that in some cases national constitutional law will have to adapt to the new, transnational liberal constitutional order created by the European Union. Hence the creation of liberal constitutional order at the EU level has entailed a challenge to liberal constitutional orders at the national level, and this challenge is indeed intrinsic to the project of European integration, but it does not need to be seen as a negative development.

As far as the weakness in the democratic responsiveness of the European Union and the tendency toward executive dominance, these are more serious problems and a challenge that urgently needs to be addressed. Most of the official reform proposals that have been contemplated in recent years have centered on further strengthening of the role of the European Parliament, or in some cases minor enhancement of the role of national parliaments in the EU process. But such reforms are unlikely to address the entrenched problems of the unresponsiveness of EU governance institutions, ${ }^{101}$ or to take sufficiently seriously the Lisbon Treaty's newly articulated commitment to EU democratic principles. ${ }^{102}$ The EU institutions-but also, it must be said, the governments of the member states themselves-have been notably ambivalent about more innovative proposals for involving civil society in European governance and deepening the democratic re-

101 See, for example, Graham Smith, Trans-national Democratic Innovation in the European Union: Flirting with Deliberative and Plebiscitary Design *9 (American Political Science Association Presentation, Aug 2013), archived at http://perma.cc/M7AH-BMPF ("Many of the evaluations of these experiments point towards the empowering effect of engagement on participants, but then regret that the outputs of these designs failed to have any effect on the European decision making process."); Committee on Constitutional Affairs, European Parliament, Method for Citizens' Direct Participation in EU Member States-Model for a More Democratic Europe *2-4 (Sept 18, 2012), archived at http://perma.cc/KYL2-45BZ. See also generally Raphaël Kies and Patrizia Nanz, eds, Is Europe Listening to Us? Successes and Failures of EU Citizen Consultations (Ashgate 2013). 102 See TEU Arts 10-12, 55 J EU C326 at 20-21. 
sponsiveness of the European Union, despite the range of interesting and ambitious suggestions that have been made in recent years. ${ }^{103}$

A willingness to undertake such reforms necessarily entails some risk, given the growth of popular opposition to the European Union in recent years, and given how EU political leaders have come to fear the use of devices like popular referenda. On the other hand, the development of direct, deliberative, and grassroots forms of engagement is crucial to build genuine democratic support for the EU project and to enable real participation on the part of the governed in the shape of EU governance. Such initiatives should not be considered as alternatives to but as supplements to the existing elements of representative democracy within the European Union. A process of reform needs to go beyond top-down or superficial forms of consultation or consent seeking based on already-completed proposals drawn up by preselected groups, and needs to be genuinely open to novel and even challenging ideas. Importantly, as others have pointed out, such democratic engagement and reform should not be undertaken merely in order to bolster the legitimacy and acceptability of previously taken steps of European integration. ${ }^{104}$ It is true that the project of opening the EU governance process more to such participatory forms of democratic engagement and contestation carries risks, not just the risk of challenging "the constitutive issues," 105 but also the risk of unmanageable governance in an already very complex system. Yet these are risks that need to be taken, if reforms are carefully designed with the risks in mind so as to strengthen European democratic and constitutional governance rather than undermine it. A willingness to engage in deeper democratic consultation and reform would also mean the European Union confronting the third of the challenges articulated above, namely the increasingly widespread opposition to the European Union's prioritization of economic integration over social goals and, more generally, to the sense that the policies of austerity

103 For examples of reform proposals, see generally Richard Youngs, The EU beyond the Crisis: The Unavoidable Challenge of Legitimacy (Carnegie Europe, Oct 2013), archived at http://perma.cc/7YPB-7AJ3; Stéphanie Hennette, et al, For a Treaty Democratizing Euro Area Governance-(T-Dem) (Social Europe, Apr 27, 2017), archived at http://perma.cc/RY6Q-M4WS; Vauchez, Democratizing Europe (cited in note 77).

104 See Youngs, The EU beyond the Crisis at 12-13 (cited in note 103).

105 Stefano Bartolini, Should the Union be 'Politicised'? Prospects and Risks, in Simon Hix and Stefano Bartolini, eds, Politics: The Right or the Wrong Sort of Medicine for the EU? *28, 44 (Notre Europe Policy Paper 19, 2006), archived at http://perma.cc/LP8W-D4M4. 
pursued in the management of the Euro crisis have undermined social democracy and other domestic welfare and constitutional commitments.

To conclude, the project of supranational European integration clearly challenges the functioning of liberal constitutional democracy at the national level in various ways and, to some extent, has posed challenges to the functioning of democracy that liberal constitutionalism is designed to protect. Some of these challenges are inevitable to a project of continent-wide integration and supranational governance, and some of them are positive challenges to particularist elements of national constitutionalism posed by the development of a system of liberal constitutionalism on this continent-wide scale. However, the lack of adequate democratic responsiveness of EU institutions, and the preference of memberstate governments for executive dominance at the supranational level are dangerous problems for the European Union. Their adverse effects on domestic constitutional democracies require serious and committed reform, if the spread not just of Euroscepticism but also of illiberal and authoritarian political forces in EU member states is to be tackled. Professor Timothy Garton Ash suggested recently that if the opposite of populism within the nationstate context is pluralism, ${ }^{106}$ then the opposite of populism within the European context is the European Union itself. ${ }^{107}$ The European Union at its best represents a response to Professor Dani Rodrik's globalization trilemma-which posits that we cannot simultaneously have deep economic integration, democratic politics, and national sovereignty, because one of the three must give ${ }^{108}$ - in its creation of a system of supranational governance in which the challenges to national constitutional democracies are compensated for by a democratically responsive system of liberal constitutionalism at the European level. But if it is indeed to meet the challenge of Rodrik's trilemma, and to meet the powerful challenges posed by the rise of populism in the European Union, the European Union must take very seriously the need for democratic and social reform and renewal of the European project.

106 For juxtaposition, see generally Jan-Werner Müller, What Is Populism? (Pennsylvania 2016).

107 T. Garton Ash, Does European Populism Exist? 4:35 (Sept 18, 2017), online at http://www.youtube.com/watch?v=bJC7JAOccfw (visited Oct 30, 2017) (Perma archive unavailable).

108 See Dani Rodrik, The Globalization Paradox: Democracy and the Future of the World Economy 200-02 (Norton 2011). 